\title{
Analysis of Lecturers' Work Performance Based on Pedagogy Competence and Work Motivation
}

\author{
Misdalina $^{1}$, Moch. Asmawi ${ }^{2}$, Bedjo Sujanto ${ }^{3}$ \\ ${ }^{1}$ Doctoral Program, Education Management, Jakarta State University and Lecturer, PGRI University of \\ Palembang, Indonesia \\ ${ }^{2}$ Lecturer, Jakarta State University, Indonesia \\ ${ }^{3}$ Lecturer, Jakarta State University, Indonesia
}

\begin{abstract}
Lecturers' work performance is one of the most crucial factors in the attainment of success of the university's vision. Thus, extra attempts need to be done in enhancing factors that influence the work performance. The objective of this research is to determine the effect of pedagogy competence and work motivation toward lecturers' work performance. The research is conducted using the quantitave approach. Research samples selected as much as 172 permanent lecturers of Universitas Persatuan Guru Republik Indonesia (UPGRI) Palembang. Foundation research data are collected through test and questionnaire. Further, data collected are analyzed using t-test and path analysis. Based on the research, it is found that: (1) there is direct positive effect of the pedagogy competence toward work performance; (2) there is direct positive effect of the work motivation toward work performance; (3) there is direct positive effect of the pedagogy competence toward work motivation. The conclusion is that work motivation needs to be firstly improved than the pedagogy competence so as to level up the work performance of UPGRI Palembang lecturers.
\end{abstract}

\section{Keywords: Work performance, Pedagogy competence, Work motivation.}

\section{Introduction}

One of the most crucial factors in the attainment of success of the university's vision is the lecturers' work performance. Lecturers' work performance is closely related to the continuity of learning and teaching process as well as the success of the school graduates. Therefore, lecturers' work performance needs to be improved. According to Kreitner and Kinicki (2014), in order to improve the work performance we need to involve the practice of cultural factors and individual differences, perception and motivation with its continuous process. Furthermore, work performance also needs supporting system. Work performance supporting system includes the situational factor, work enhancement cycle and the wanted results. This means that in the work enhancement cycle, we need to emphasize on the goal setting, feedback and training, work appreciation as well as the positive affirmation. These are in accordance with Colquitt et al. (2015) who stated that organizational behavior which includes individual characteristics, group mechanism and organization mechanism influence the individual mechanism which includes job satisfaction, stress, motivation, trust, justice, ethics, learning and decision maker, and eventually will affect the individual outcome which includes the work performance and organizational commitment. In other words, we need positive individual behavior in our attempts to improve and enhance the work performance.

In fact, the impact of work performance of the permanent lecturers at UPGRI Palembang in 2016 demonstrates that $22 \%$ out of 350 lecturers who spread out over 24 study programs, has teaching certificates. The data, however, shows the insufficient work performance which may cause 
by many factors. This can be seen from UPGRI Palembang Report in 2016 (2017); there were 65 research titles done by 65 lecturers, 5 research titles from lecturers who got research grant from UPGRI Palembang, there were only 8 lecturers who got research grant from The Ministry of Research, Technology and Higher Education in 2014 and 2015, and 26 lecturers who got research grant in 2016. Furthermore, there were 30 proposals done by the junior lecturers of UPGRI who attended the research methodology training, lecturers who attended research methodology training on national grant which was held by a body named Kopertis Wilayah II and The Ministry of Research, Technology and Higher Education, lecturers' training on scientific writing which produced 30 scientific writing pieces by UPGRI Palembang lecturers. These are the tangible efforts done by UPGRI Palembang to shove their lecturers to work better. Yet, of course the lecturers' attitude does matter, whether they want to study harder to foster their individual characteristics. Also, strive for individual mechanism so that the designated work performance can be successfully achieved. Thus, it is needed further investigation on factors that affect the work performance.

Few research results show that work performance is influenced by certain factors. Based on Raja's research results (2016), he stated that work commitment slightly affects our work, yet work motivation highly affects our work and at the same time highly affects our work performance. Furthermore, Andersson and Roxa (2004) emphasized about the importance of pedagogy capability in creating good teaching and learning. Coherently with Koniga and Rothland (2012), general knowledge on pedagogy correlates positively with intrinsic motivation.

Based on these research's results, there are few factors that influence work performance. In this case, what matters most to be investigated is which factors that urgently needed to be fixed and boost up.

\section{Objectives}

In general, this study aims to picture out the most prominent factors that need to be boost up for the lecturers in achieving the vision of the university as well as becoming individual objectives of each lecturer. Particularly, this research aims to find out: (1) the direct effect of pedagogy competence to work performance, (2) direct effect of work motivation to work performance, (3) direct effect of pedagogy competence to work motivation.

\section{Literature Review}

\section{Work Performance}

Smither and London (2009) stated that as the result of task given by the organization, work performance should be truly done or conducted. Work performance nonetheless is the result of something done by one person himself. Therefore, it can be clarified work performance correlates with the obtained results of doing something that becomes his or her responsibility. Furthermore, Colquitt et al. (2015) stated that work performance correlates with something given or donated from a set of behaviour in conducting his or her duty positively so as to achieve the objective of the organization. Similarly, Ivancevich et al. (2014) stated that work performance is a set of behaviour which can affect someone's work performance that suits the objective of the organization. Moreover, Ivancevich et al. (2014) stated that work performance includes results which possess value both for the organization and the person himself/herself. Obviously, work performance can be defined as results which possess value for the organization and each individual obtained from set of certain behavior.

On the other hand, Mathis and Jackson (2006) pointed out that work performance is the act related with the amount of conducted activities which is qualified enough, results of following the activity suits with the agreed target, following the activity is in coherent the designated day and finally can cooperate well with others during the activity. Agree with Edison et al. (2016), work performance correlates with work results which are the products of one's activity, done in 
accordance with the designated time with its designated reference and measurement.

Based on the above opinions, it can be synthesized that work performance means someone's work proof or someone's effort in conducting the given task which becomes his or her responsibility within the designated time given.

\section{Pedagogy Competence}

According to Wistoft (2009), pedagogy competence is included as value clarification. Value clarification which challenges the medical counselor to set up their knowledge, norm and understanding, as well as defines the meaning of health for common people. Ryegard et al. (2010) stated that "pedagogical competence implies that the teacher from definite goals and frameworks, through continuous development of teaching and personal professional development, supports and facilitates the learning of the student in the best way". Whereas, Madhavaram dan Laverie (2010) defines pedagogy competence as someone's ability to make use of the combination of tangible, coordinated and synergized resources so as to achieve the efficiency in pedagogy. Thus, all possessed capability is coordinated synergistically for efficiency in pedagogy. Additionally, Hellriegel dan Slocum (2011) stated that competence is the accumulation of knowledge, skills and ability which are interrelated and needed by individuals, team or one organization in their efforts to achieve effective work performance.

On the other hand, Colquit et al. (2015) stated that competence is someone's conviction on his/her capability in fulfilling his work target and finally succeeded with his/her work. Furthermore, Zainuddin et al. (2014) defined pedagogy competence as the capability of managing students' learning which includes understanding of the students' background, planning and conducting learning process, evaluation of students' learning, and students' development program so that they can actualize their individual potential.
Based on the above definition of pedagogy competence, it can be synergized that pedagogy competence is knowledge capability owned by one person in managing learning as education, observation and training which can be fully developed in the future as long as it is equipped with consistent training.

\section{Work Motivation}

Luthans (2011) defined motivation as a process that begins with psychological deficiency or psychology that drives up behavior or encouragement for an objectives or intention. Furthermore, McShane dan Ann (2009) stated that motivation refers to the encouragement one person has which influences his or her direction, intensity, perseverance and voluntary behaviour. Other scholars, Ivancevich (2007) defined motivation as a set of attitude which influences someone to act for specific and directed objectives. Motivation is defined as one deep power that can offer power, direction and human behaviour support to achieve the goal. People will work harder with hope that they can fulfill their needs and wants from the work they have done. According to Santrock (2011), motivation involves a process that gives out the energy, direct and maintains behaviour. In other words, motivated behavior means behavior that is given out the energy, directed and simultaneous.

Other scholars, Kreitner dan Kinicki (2014) stated about Vroom's theory of expectancy. Vroom assumed that people are motivated to behave in certain ways, which then create the wanted combination upon the wanted results. Furthermore, people are becoming motivated when they are assured that they can accomplish their work and get reward of what they have tried and successfully accomplished. There are three important concepts in Vroom's theory of expectancy. They are expectancy, instrumentality, and valence. Expectancy represents someone's belief that the effort level will be simultaneously followed by work performance level. This means, if you work harder then you will get high work performance. The higher our expectancy, the higher is the motivation. Convinced they can 
accomplish their tasks. Instrumentality represents someone's belief that work performance plays a very important role in leading our direction. This means, we believe that work performance will lead us to get results or a reward. Overall achievement relies on the work performance. The more productive we are, the more results we will get. Valence leads to positive or negative value which is referred to the acquired results. Additionally, valence reflects someone's personal preference. The higher is the valence, more opportunities for the motivation to bloom.

Based on the above opinions, it can be synthesized that motivation means "something that initiates spirit or encouragement to work optimally in achieving the designated objective of the organization which is influenced by the ability to fulfill employee's needs.

\section{Research Methodology}

This is a quantitative research using a survey method. The target population of this research is 301 of the permanent lecturers of the foundation. Research samples selected as much as 172 lecturers using simple random sampling technique. Data collecting for this research through test and questionnaire. Lecturers as the research respondents are given test of pedagogy competence and work motivation questionnaire, whereas the questionnaire of lecturers' work performance is given to Head of Study Programme. Test given is in form of guided questions which are designed and developed from theory analysis of pedagogy competence. On the other hand, the questionnaire given is in form of guided statements which are designed and developed from the relevant theory that concerned on construct validity. Construct validity means the statements are designed based on the suitable and related theory which then made into synthesis along with the indicators of each variable. Research data is analyzed using t-test and path analysis. These techniques are used to see which independent variables are dominant directly and indirectly affect the dependent variables.

\section{Result}

Based on the research, it is found the correlation between pedagogy competence and work performance as much as 0,496 (can be seen in Table 1). Hypothesis testing result can be seen in Table 2 (the decision of each hypothesis and the estimated path coefficient).

Table 1: Correlation

\begin{tabular}{|c|c|c|c|}
\hline & $\mathrm{X}_{1}$ & $\mathrm{X}_{2}$ & $\mathrm{Y}$ \\
\hline $\mathrm{X}_{1}$ & 1 & & \\
\hline $\mathrm{X}_{2}$ & 0,584 & 1 & \\
\hline $\mathrm{Y}$ & 0,496 & 0,584 & 1 \\
\hline
\end{tabular}

Table 2: Hypothesis Testing Result

\begin{tabular}{|c|c|c|c|c|c|}
\hline \multicolumn{2}{|c|}{ Variable } & $\begin{array}{c}\text { Path } \\
\text { Coefficients }\end{array}$ & $\mathrm{t}_{\text {count }}$ & $\mathrm{t}_{\text {table }}$ & Sig. \\
\hline $\mathrm{Y}$ & $\mathrm{X}_{1}$ & 0,235 & 3,14 & 1,65 & 0,00 \\
\hline $\mathrm{Y}$ & $\mathrm{X}_{2}$ & 0,447 & 5,98 & 1,65 & 0,00 \\
\hline $\mathrm{X}_{2}$ & $\mathrm{X}_{1}$ & 0,584 & 9,38 & 1,65 & 0,00 \\
\hline
\end{tabular}

\section{Discussion}

\section{Effect of Pedagogy Competence toward Work Performance}

The result of hypothesis 1 testing shows that $\mathrm{t}_{\text {count }}$ $(3,14)$ is bigger than $t_{\text {table }}(1,65)$ and significant value $(0,00)$ is less than 0,05 . This means that there is positive, significant, direct effect of pedagogy competence toward work performance. The effect demonstrates that pedagogy competence is the prominent point needed for boosting up lecturers' work performance. This is in accordance with Robbins and Judge's opinions (2013) that ability is closely related with work performance. Diaconu and Jinga (Suciu and Mata, 2011) stated that pedagogy competence stresses on the work performance for varied algorithm methodology in accomplishing all teaching duties. Finally, this is also supported by one research done by Hakim (2015) which stated that pedagogy capability implies effect in boosting up our work.

\section{Effects of Work Motivation toward Work Performance}

The result of hypothesis 2 testing shows that $t_{\text {count }}$ $(5,98)$ is bigger than $t_{\text {table }}(1,65)$ and significant value $(0,00)$ is less than 0,05 . This means that there is positive, significant direct effect of work 
motivation toward work performance. The effect demonstrates that someone's effort to work and get the wanted value is the prominent point in boosting up lecturers' work performances. The fact is in accordance with Gibson et al. (2012) who stated that motivation and the ability interact with each other in determining the work performance. This is also supported by the research of Haryono and Arafat (2017) which stated that there is significant and positive correlation between motivation and work performance.

\section{Effects of Pedagogy Competence toward Work Motivation}

The result of hypothesis 3 testing shows that $t_{\text {count }}$ $(9,38)$ is bigger than $t_{\text {table }}(1,65)$ and significant value $(0,00)$ is less than 0,05 . This means that there is positive, significant direct effect of pedagogy competence toward work motivation. Thus, the effect shows that the ability of pedagogy knowledge is urgently needed for someone to work harder to obtain the wanted value. This is in accordance with Robbins and Judge (2013) who stated that ability means individual capacity in doing varied assignments of their work. Finally, this is also supported by a research of Konig and Rothland (2012) which stated that pedagogy competence correlates positively with intrinsic motivation.

\section{Direct and Indirect Effects}

Direct effect of pedagogy competence toward work performance is 0,235 , where as the indirect effect of pedagogy competence toward work motivation as the intervening variable is 0,261 . Thus, the obtained results of the direct and indirect effect of pedagogy competence toward work motivation and work satisfaction as the intervening variable is 0,496 . The result shows that it is similar with the correlation value between pedagogy competence and work performance. Therefore, it can be concluded that work motivation is the intervening variable of pedagogy competence and work performance. This is supported the opinion of Colquitt et al. (2015) which stated that individual characteristics such as capability as the independent variable affects individual results such as work performance as the dependent variable with individual mechanism such as work motivation as the intervening variable.

\section{Conclusion}

Based on the results of hypothesis testing, related theory and supported research results, it is found that: (1) there is a significant, positive and direct effect of the pedagogy competence toward work performance, (2) there is significant positive effect of work motivation toward work performance and (3) there is significant and direct effect of pedagogy competence toward work motivation. Meanwhile, based on the direct and indirect effect, it can be concluded that work motivation plays a role as the intervening variable and implies more significant direct effect to work motivation compared to pedagogy competence toward work motivation. Thus, prioritize the work motivation to pedagogy competence is significant in boosting the work performance of the lecturers at UPGRI Palembang.

\section{References}

[1] R. Kreitner \& A. Kinicki, Organizational Behavior, Eight Edition, Translation Biro Bahasa Alkemis, Jakarta, Salemba Empat, 2014.

[2] J. Colquitt, J.A. Jeffery, \& M.J. Wesson, Organizational Behavior; Improving Performance and Commitment in the Workplace, New York, McGraw-Hill Irwin, 2015.

[3] UPGRI Palembang, Reports on Work Program of 2016.

[4] W.J. Smither \& M. London. (Ed), Performance Management, San Fransisco, Jossey Bass, 2009.

[5] John M. Ivancevich, Robert Konopaske, Michael T. Matteson. Organizational behavior \& Management, Tenth Edition, New York, McGraw-Hill Education, 2014.

[6] R.L. Mathis \& John H Jackson. Human Resource Management, Thirteenth Edition, USA: South-Westrn Cengange Learning, 2011. 
[7] E. Edison, Y. Anwar, I. Komariyah, Human Resource Management; Strategy and Change in Order to Improve Employee and Organization Performance, Bandung, Alfabeta, 2016.

[8] Ryegard, T. Olsson, \& K. Apelgren, A Swedish Perspective on pedagogical Competence, Swedish, Uppsala University, 2010.

[9] D. Hellriegel \& J.W. Slocum. Organizational Behavior, USA: SouthWestrn Cengage learning, 2011.

[10] M. Zainuddin, I. Hanafi, D. Kustono, Kumaidi, Y. Haroen. E. Kuswarno, B. Sugiarto, S. Azwar, C.K. Wachjoe, S. Winarno, Educator Certification Manual for Integrated Lecturers. Terintegrasi. Book I. Academic Paper, Direktorat Jenderal Pendidikan Tinggi Kementerian Pendidikan dan Kebudayaan, 2014.

[11] F. Luthans, Organization Behavior, An Evidence-Based Approach, Twelfth Edition, New York: McGraw-Hill International, 2011.

[12] McShane dan V. Glinow, Organizational behavior, Emerging Knowledge and Practice for the Real World. Fifth Edition, New York: McGraw-Hill/Irwin, 2010.

[13] J.W. Santrock, Educational Psychology, Fifth Edition, New York: McGraw-Hill, 2011.

[14] J.L. Gibson, J.M. Ivancevich, J.H. Donnelly. Jr, R. Konopaske, Organization behavior, Structure, Processes, New York, McGraw Hill, 2012.

[15] S.P. Robbins and T.A. Judge, Organization Behavior, New Jersey, Pearson Education, Inc., 2013.

[16] P. Andersson \& T. Roxa, "The pedagogical academy: a way to encourage and reward scholarly teaching," European Journal of Engineering Education, XXIX (4), pp. 559-569, 2004.

[17] J. Königa and M. Rothland, "Motivations for choosing teaching as a career: effects on general pedagogical knowledge during initial teacher education," Asia-Pacific
Journal of Teacher Education, XL (3), pp. 289-315, 2012.

[18] S. Haryono \& Y. Arafat, "Effects of Organizational Culture and Work Motivation on Job Performance Among the Private 1Jniversities' Full-time Faculties in South Sumatera Province," Journal International Information Institute, XX (8A), pp. 5563-5575, 2017.

[19] T.H.L. Raja, "The Effect of Job Commitment and Motivation Towards Employees' Work at Office of Health Department in Langkat Regency," Jounal of Arts, Science \& Commerce, VII (1), pp. 60-69, 2016.

[20] A.I. Suciu and L. Mata, "Pedagogical Competences- The Key to Efficient Education," International Online Journal of Educational Sciences, III (2), pp. 411423, 2011.

[21] K. Wistoft, "Pedagogical Competence and Value clarification Among Health Educators," Sage Journal, IUHPE - Global Health Promotion, XVI (3), pp. 24-34, 2009.

[22] S. Madhavaram and D.A. Laverie, Developing Pedagogical Competence: Issues and Implications for Marketing. Journal of Marketing Education, SAGE Publications, XX (10), pp. 1-17, 2010.

[23] Hakim, "Contribution of Competence Teacher (Pedagogical, Personality, Professional Competence and Social) On the Performance of Learning," The International Journal of Engineering and Science (IJES), IV (2), pp. 01-12, 2015. 